\title{
ANTIBACTERIAL ACTIVITY TEST SEA CUCUMBER EXTRACT (Holothuria scabra) SIDAYU COAST GRESIK USING DISK DIFFUSION METHOD
}

\author{
Haris Nursyah Arifin, Rachmawati Ningsih, Avin Ainur Fitrianingsih, Abdul Hakim \\ Jurusan Kimia, Fakultas Sains dan Teknologi UIN Maulana Malik Ibrahim Malang \\ Corresponding author : nastklenk69@gmail.com
}

\begin{abstract}
Sea cucumber (Holothuria scabra) is one kind of sea cucumbers that contains of bioactive compound that can inhibit bacteria growth. This research aim to know the effect of methanol and $n$-hexane extract towards bacterium Staphylococcus aureus, Salmonella typhi and Escherichia coli bacterial growth and to identification estimation active compound group.

Sea cucumbers active compound extraction using maceration method with methanol and $n$-hexane as a solvent. Methanol and $n$-hexane crude extract conducted antibacterial assay using disk diffusion method towards bacterium Staphylococcus aureus, Salmonella typhi, Escherichia coli and continued with reagent test to knowing active compound group.

The result of this research indicated that $n$-hexane extracts provide the best inhibition zone toward bacterium Escherichia coli at concentration $2000 \mathrm{ppm}$ with among of inhibition zone 1,75 mm, while at bacterium Staphylococcus aureus and Salmonella typhi does not provide inhibition zone. Methanol extract does not provide inhibition zone towards bacterium Staphylococcus aureus, Salmonella typhi and Escherichia coli. The result of reagent test indicated compound that detected in $n$-hexane extract is saponins.
\end{abstract}

Keywords: sea cucumbers (Holothuria scabra), disk diffusion, extraction, antibacterial, Staphylococcus aureus, Salmonella Typhi, and Escherichia coli.

\section{ABSTRAK}

Teripang pasir (Holothuria scabra) merupakan salah satu jenis teripang yang mengandung senyawa bioaktif yang dapat menghambat pertumbuhan bakteri. Penelitian ini bertujuan untuk mengetahui pengaruh ekstrak metanol dan n-heksana terhadap pertumbuhan bakteri Staphylococcus aureus, Salmonella typhi dan Escherichia coli serta mengidentifikasi dugaan golongan senyawa aktif.

Ekstraksi senyawa aktif teripang pasir menggunakan metode maserasi dengan pelarut metanol dan nheksana. Ekstrak kasar metanol dan n-heksana dilakukan uji antibakteri menggunakan metode difusi cakram terhadap bakteri Staphylococcus aureus, Salmonella typhi, Escherichia coli dan dilanjutkan dengan uji reagen untuk mengetahui golongan senyawa aktif.

Hasil penelitian ini menunjukkan bahwa ekstrak n-heksana memberikan zona bening terbaik pada konsentrasi 2000 ppm dengan rata-rata zona bening 1,75 mm terhadap bakteri Escherichia coli, sedangkan pada bakteri Staphylococcus aureus dan Salmonella typhi tidak memberikan zona bening. Ekstrak metanol tidak memberikan zona bening terhadap bakteri Staphylococcus aureus, Salmonella typhi dan Escherichia coli. Hasil uji fitokimia menunjukkan senyawa yang terdeteksi dalam ekstrak n-heksana adalah saponin.

Kata Kunci: teripang pasir (Holothuria scabra), difusi cakram, ekstraksi, antibakteri, Staphylococcus aureus, Salmonella Typhi, dan Escherichia coli.

\section{PENDAHULUAN}

Indonesia adalah salah satu negara kepulauan yang memiliki garis pantai terpanjang di dunia dengan panjang 81.000 $\mathrm{km}$ dengan luas perairan laut sekitar 5,8 juta $\mathrm{km} 2(75 \%$ dari total Wilayah Indonesia) (Dewi et al., 2010). Hasil laut yang mempunyai nilai penting salah satunya adalah teripang pasir.
Teripang dapat ditemukan hampir di seluruh perairan pantai, mulai daerah pasang surut yang dangkal sampai perairan yang lebih dalam. Menurut Martoyo et al. (2000), teripang kering memiliki kandungan protein $82 \%$, lemak 1,7 \%, air $8,9 \%$, abu $8,6 \%$, dan karbohidrat $4,8 \%$. Bordbar et al. (2011), menjelaskan kandungan senyawa aktif teripang adalah 
triterpen glikosida (saponin), kondroitin sulfat, glikosaminoglikan, sterol, sulfat triterpen glukosa, sulfat polisakarida, peptida, protein (gelatin dan kalogen), hidrosalisilat, glikoprotein, lektin, fenol dan flavonoid. Senyawa yang terkandung dalam teripang pasir salah satunya adalah saponin yang dapat berpotensi sebagai antibakteri.

Farouk (2007), menjelaskan ekstrak teripang Holothuria atra dapat menghambat pertumbuhan bakteri Staphylococcus aureus dan Escherichia coli. Wawolumaya (2012), juga menjelaskan bahwa ekstrak n-heksana teripang Stichopus hermanii dan Stichopus sp. memiliki aktivitas antibakteri terhadap bakteri Bacillus subtilis dan Staphylococcus aureus.

Tujuan dari penelitian ini adalah untuk mengetahui aktivitas antibakteri ekstrak teripang pasir (Holothuria scabra) dari Pantai Sidayu Gresik, yang diekstrak dengan dua jenis pelarut, yaitu metanol dan $n$-heksana hasil destilasi. Hasil dari penelitian ini nantinya diaplikasikan sebagai sumber senyawa antibakteri.

\section{METODE PENELITIAN}

Bahan

Bahan yang digunakan dalam penelitian ini adalah teripang pasir (Holothuria scabra) yang diperoleh dari Pantai Sidayu Gresik.

\section{Analisis Kadar Air}

Analisis kadar air dilakukan pada bagian tubuh teripang pasir (Holothuria scabra). Sebelumnya cawan dipanaskan dalam oven pada suhu $100-105{ }^{\circ} \mathrm{C}$ selama 15 menit untuk menghilangkan kadar airnya, kemudian cawan disimpan dalam vacum desikator sekitar 10 menit. Cawan tersebut selanjutnya ditimbang dan dilakukan perlakuan yang sama sampai diperoleh berat cawan yang konstan. Sampel teripang pasir basah dimasukkan ke dalam cawan yang telah diketahui berat konstannya. Sampel yang sudah dipotong kecil-kecil diambil 5 gram dan dikeringkan ke dalam oven pada suhu $100-105{ }^{\circ} \mathrm{C}$ selama 15 menit untuk menghilangkan kadar air dalam tubuh teripang pasir, kemudian sampel disimpan dalam vacum desikator selama 10 menit dan ditimbang. Sampel tersebut dipanaskan kembali dalam oven 15 menit, didinginkan dalam vacum desikator dan ditimbang kembali. Perlakuan ini diulangi sampai berat konstan.

\section{Uji Kadar Garam}

Teripang pasir basah ditimbang sebanyak 10 gram. Diekstrak menggunakan aquades panas $100 \mathrm{~mL}$, didiamkan selama \pm 1 menit, kemudian disaring dengan kertas saring. Hasil yang diperoleh diteteskan pada prisma pembaca pada salinometer ATAGO PAL-06. Garam dalam larutan tersebut diukur sebagai konsentrasi kepekatan \%o.

\section{Preparasi Sampel}

Teripang pasir diambil seluruh bagian tubuh, di buang kotoran dalam teripang kemudian dicuci, diiris kecil-kecil, selanjutnya diblender.

\section{Ekstraksi Sampel}

Metode ekstraksi yang adalah metode ekstraksi maserasi. Teripang ditimbang 200 gram kemudian direndam dalam metanol dan $n$-heksana $400 \mathrm{~mL}$ selama 24 jam dan dishaker selama 5 jam dengan kecepatan $150 \mathrm{rpm}$. Ampas direndam kembali sampai tiga kali pengulangan sampai filtrat yang didapat bening, sehingga diperoleh senyawa aktif. Filtrat disaring dari ampasnya menggunakan vacum buchner, ketiga filtrat yang diperoleh digabungkan. Pelarut metanol dan $n$-heksana diuapkan dengan rotary evaporator pada suhu $40{ }^{\circ} \mathrm{C}$ untuk mendapatkan ekstrak kasar. Ekstrak kasar metanol dan $n$-heksana dimasukkan ke dalam vacum desikator untuk memekatkan ekstrak. Selanjutnya ekstrak yang diperoleh dihitung rendemennya.

Ekstrak pekat metanol dan $n$ heksana yang diperoleh diuji aktivitas antibakterinya. 


\section{Uji Aktivitas Antibakteri Menggunakan Metode Difusi Cakram \\ 1. Sterilisasi Alat dan Bahan}

Alat-alat yang digunakan untuk uji aktivitas antibakteri disterilkan dengan cara memasukkan ke dalam autoklaf selama 15 menit pada suhu $121{ }^{\circ} \mathrm{C}$ dan tekanan 15 psi (per square inchi). Alat-alat yang tidak tahan tehadap panas tinggi disterilkan dengan menyiram alat dengan menggunakan etanol $70 \%$ (Volk dan Wheeler, 1993).

\section{Pembuatan Nutrient Agar}

Pembuatan media dilakukan dengan melarutkan 4,6 g nutrien agar dalam 200 $\mathrm{mL}$ akuades pada beaker gelas. Suspensi yang dihasilkan dipanaskan sampai mendidih, kemudian dimasukkan dalam erlenmeyer ditutup dengan kapas dan wrap kemudian disterilisasi. Proses sterilisasi menggunakan autoklaf pada suhu $121{ }^{\circ} \mathrm{C}$ dengan tekanan 15 psi selama 15 menit (Volk dan Wheeler, 1993).

\section{Pembuatan Media Agar Miring}

Media agar miring dibuat dengan memasukkan media agar yang telah selesai dipanaskan (tahap 3.5.5.3) sebanyak $5 \mathrm{~mL}$ ke dalam tabung reaksi lalu ditutup menggunakan kapas dan plastik wrap. Media dalam tabung dimasukkan dalam plastik tahan panas dan disterilisasi menggunakan autoklaf pada suhu $121{ }^{\circ} \mathrm{C}$ dengan tekanan 15 psi selama 15 menit. Proses sterilisasi selesai tabung diposisikan dalam keadaan miring.

\section{Peremajaan Biakan Murni Bakteri}

Biakan murni bakteri diremajakan pada media padat agar miring dengan cara menggoreskan jarum ose yang mengandung bakteri Staphylococcus aureus, Salmonella typhi dan Escherichia coli secara aseptis yaitu dengan mendekatkan mulut tabung pada nyala api saat menggoreskan jarum ose. Tabung reaksi ditutup kembali dengan kapas dan diinkubasi selama 18-24 jam pada suhu $37{ }^{\circ} \mathrm{C}$ dalam inkubator.

\section{Pembuatan Nutrient Bort}

Pembuatan media dilakukan dengan melarutkan $0,9 \mathrm{~g}$ nutrien bort dalam 100 $\mathrm{mL}$ akuades pada beaker gelas. Suspensi yang dihasilkan dipanaskan sampai mendidih, kemudian dimasukkan dalam erlenmeyer ditutup dengan kapas dan wrap kemudian disterilisasi. Proses sterilisasi menggunakan autoklaf pada suhu $121{ }^{\circ} \mathrm{C}$ dengan tekanan 15 psi selama 15 menit.

\section{Pembuatan Larutan Biakan Aktif}

Satu ose bakteri hasil peremajaan biakan murni dibiakkan dalam $10 \mathrm{~mL}$ media agar cair steril dan dihomogenkan. Larutan ini berfungsi sebagai biakan aktif.

\section{Uji Aktivitas Antibakteri}

Uji aktivitas antibakteri menggunakan konsentrasi ekstrak metanol 500 ppm, 1000 ppm, 1500 ppm, 2000 ppm dan 25.000 ppm, 50.000 ppm, 75.000 ppm, 100.000 ppm. Konsentrasi ekstrak $n$-heksana adalah 500 ppm, 1000 ppm, 1500 ppm, 2000 ppm. Konsentrasi kontrol positif ampisilin 0,4 $\mathrm{mg} / \mathrm{mL}$ dan streptomisin $6,25 \mathrm{mg} / \mathrm{mL}$.

Langkah pertama yaitu membuat variasi konsentrasi ekstrak dan kontrol sesuai konsentrasi di atas. Kertas cakram (diameter $5 \mathrm{~mm}$ ) diresapkan dalam ekstrak metanol, $n$-heksana dan larutan kontrol. Proses peresapan dilakukan dengan cara merendamkan kertas cakram pada ekstrak metanol, $n$-heksana, kontrol positif antibiotik dan kontrol negatif pelarut selama 30-60 menit.

Langkah kedua, larutan biakan aktif bakteri diambil sebanyak $50 \mu \mathrm{L}$ dan dimasukkan ke dalam cawan petri steril. Media agar padat (tahap 3.5.5.2) dipanaskan sampai mencair, kemudian didinginkan sampai suhu $40 \quad{ }^{\circ} \mathrm{C}$ dan dituangkan ke dalam cawan petri yang berisi larutan biakan aktif bakteri. Media agar padat dan larutan biakan aktif bakteri dihomogenkan dan dibiarkan hingga memadat. Kertas cakram kemudian diletakkan di atas permukaan media bakteri menggunakan pinset dan ditekan sedikit. Selanjutnya, diinkubasi pada suhu $37{ }^{\circ} \mathrm{C}$ 
selama \pm 24 jam. Kemudian, diukur zona hambatannya dengan menggunakan penggaris. Luas zona hambatan ditentukan dengan cara mengurangi diameter keseluruhan (cakram + zona hambatan) dengan diameter cakram dan diameter zona hambat pelarut (jika pelarut memberikan zona hambat).

Uji aktivitas antibakteri bertujuan untuk mengetahui pengaruh ekstrak metanol dan $n$-heksana terhadap bakteri Staphylococcus aureus, Salmonella typhi dan Escherichia coli.

\section{Uji Kandungan Senyawa Aktif dengan Uji Reagen \\ Uji Alkaloid}

Ekstrak teripang pasir dimasukkan dalam tabung reaksi, ditambah $0,5 \mathrm{~mL} \mathrm{HCl}$ $2 \%$ dan larutan dibagi dalam dua tabung. Tabung I ditambahkan 2 - 3 tetes reagen Dragendorff, tabung II ditambahkan 2 - 3 tetes reagen Mayer. Jika tabung I terbentuk endapan jingga dan pada tabung II terbentuk endapan kekuning-kuningan, menunjukkan adanya alkaloid.

\section{Uji Flavonoid}

Ekstrak teripang pasir dimasukkan dalam tabung reaksi kemudian dilarutkan dalam 1 - $2 \mathrm{~mL}$ metanol panas $50 \%$. Setelah itu ditambah logam $\mathrm{Mg}$ dan 4 - 5 tetes $\mathrm{HCl}$ pekat. Larutan berwarna merah atau jingga yang terbentuk, menunjukkan adanya flavonoid.

\section{Uji Saponin}

Ekstrak teripang pasir dimasukkan dalam tabung reaksi ditambah air (1:1) sambil dikocok selama 1 menit, apabila menimbulkan busa ditambahkan $\mathrm{HCl} 1 \mathrm{~N}$, busa yang terbentuk dapat bertahan selama 10 menit dengan ketinggian $1-3 \mathrm{~cm}$, maka ekstrak positif mengandung saponin.

\section{Uji Triterpenoid dan Steroid}

Ekstrak teripang pasir dimasukkan dalam tabung reaksi, dilarutkan dalam 0,5 $\mathrm{mL}$ kloroform kemudian ditambah dengan
0,5 $\mathrm{mL}$ asam asetat anhidrat. Campuran ini selanjutnya ditambah dengan $1-2 \mathrm{~mL}$ $\mathrm{H}_{2} \mathrm{SO}_{4}$ pekat melalui dinding tabung tersebut. Jika hasil yang diperoleh berupa cincin kecoklatan atau violet pada perbatasan dua pelarut menunjukkan adanya triterpenoid, sedangkan jika terbentuk warna hijau kebiruan menunjukkan adanya steroid.

\section{HASIL DAN PEMBAHASAN Preparasi Sampel}

Sampel yang digunakan dalam penelitian ini adalah teripang pasir (Holothuria scabra) Pantai Sidayu Gresik. Teripang yang digunakan adalah teripang basah yang masih segar dan tidak dilakukan pengeringan untuk menjaga senyawa aktif dalam teripang agar tidak rusak akibat suhu yang terlalu tinggi. Bagian luar dan dalam tubuh teripang dibersihkan dari kotoran dan organ pencernaan untuk meminimalisir adanya kontaminasi yang nantinya akan berpengaruh pada hasil pengujian. Proses pemblenderan dilakukan untuk memperkecil ukuran sampel. Semakin kecil ukuran sampel, maka luas permukaan semakin banyak dan proses ekstraksi akan berlangsung lebih efektif karena interaksi antara pelarut dengan senyawa dalam teripang semakin besar.

\section{Analisis Kadar Air}

Analisis kadar air menurut Winarno, 2002 dilakukan dengan metode pemanasan menggunakan oven pada suhu $100-105^{\circ} \mathrm{C}$ sampai berat sampel konstan. Hasil uji kadar air teripang pasir diperoleh sebesar $77,83 \%$.

Kadar air yang terlalu tinggi memungkinkan daya simpan sampel menjadi rendah. Kadar air sampel yang tinggi sebesar $77,83 \quad \%$ tidak memungkinkan sampel disimpan terlalu lama sehingga harus langsung digunakan (preparasi) karena dimungkinkan sampel akan rusak karena ditumbuhi jamur dan mikroba. 


\section{Analisis Kadar Garam}

Hasil pengukuran kadar garam teripang pasir diperoleh sebesar $2 \%$. Kadar garam sampel sangat berpengaruh terhadap pertumbuhan bakteri uji. Konsentrasi 10-15 $\%$ kadar garam umumnya sudah cukup untuk membunuh sebagian besar jenis-jenis bakteri (Hudaya dan Darajat, 1980). Sehingga kadar garam pada sampel tidak berpengaruh terhadap bakteri uji.

\section{Ekstraksi Sampel}

Ekstraksi yang digunakan pada penelitian ini untuk mengekstrak teripang pasir menggunakan ekstraksi maserasi dengan pelarut methanol dan $n$-heksana.

Rendemen hasil ekstraksi pada penelitian ini masing-masing yaitu metanol $(3,983 \%)$ dan $n$-heksana $(0,089 \%)$.

\section{Uji Aktivitas Antibakteri Menggunakan Metode Difusi Cakram}

Variasi konsentrasi ekstrak metanol yang digunakan adalah 500 ppm, 1000 ppm, $1500 \mathrm{ppm}, 2000 \mathrm{ppm}$ dan 25.000 ppm, 50.000 ppm, 75.000 ppm, 100.000 ppm. Variasi konsentrasi ekstrak $n$-heksana adalah 500 ppm, 1000 ppm, 1500 ppm, $2000 \mathrm{ppm}$.

Hasil uji aktivitas antibakteri terhadap ekstrak metanol tidak memiliki zona bening terhadap bakteri Staphylococcus aureus, Salmonella typhi dan Escherichia coli. Ekstrak $n$-heksana memiliki zona bening disekitar cakram hanya terhadap pada bakteri Escherichia coli dan tidak memberikan zona bening pada bakteri Staphylococcus aureus dan Salmonella typhi. Hasil uji aktivitas antibakteri ekstrak $n$-heksana teripang pasir ditunjukkan pada Tabel 4.1

Tabel 4.1 Hasil uji aktivitas antibakteri ekstrak $n$-heksana teripang pasir.

\begin{tabular}{|c|c|c|c|}
\hline $\begin{array}{c}\text { Kon } \\
\text { sentrasi } \\
\text { Ekstrak } \\
(\text { ppm) } \\
\end{array}$ & $\begin{array}{c}\text { Kon } \\
\text { sentrasi } \\
\text { Bakteri } \\
(\text { CFU/mL) } \\
\end{array}$ & $\begin{array}{c}\text { Dia } \\
\text { meter } \\
\text { Zona Ham } \\
\text { bat }(\mathbf{m m})\end{array}$ & $\begin{array}{c}\text { Nota } \\
\text { si } \\
\text { (BNT) }\end{array}$ \\
\hline 2000 & \multirow{3}{*}{$1,03 \times 10^{9}$} & 1,75 & $\mathrm{~b}$ \\
\hline 1500 & & 1,5 & $\mathrm{a}$ \\
\hline 1000 & & - & $\mathrm{a}$ \\
\hline
\end{tabular}

\begin{tabular}{|c|c|c|c|}
\hline 500 & \multirow{4}{*}{$1,03 \times 10^{9}$} & - & $\mathrm{a}$ \\
\cline { 4 - 4 } \begin{tabular}{c} 
Kontrol \\
\cline { 3 - 4 } \\
\cline { 3 - 4 } misin
\end{tabular} & - & - \\
\cline { 3 - 4 } & & 13 & - \\
\hline
\end{tabular}

Ekstrak $n$-heksana dapat menghasilkan zona bening karena mengandung senyawa aktif antibakteri yaitu saponin (Hasil uji reagen). Saponin dapat melarutkan lemak sehingga dapat menurunkan tegangan permukaan sel yang dapat menghancurkan sel bakteri (Wawolumaya, 2012).

\section{Uji Kandungan Senyawa Aktif Menggunakan Uji Reagen}

Hasil uji reagen ekstrak teripang pasir ditunjukkan pada Tabel 4.2 berikut :

Tabel 4.2 Hasil uji reagen ekstrak teripang pasir

\begin{tabular}{|l|c|c|}
\hline \multicolumn{1}{|c|}{ Uji Reagen } & $\begin{array}{c}\text { Fraksi } \\
\text { metanol }\end{array}$ & $\begin{array}{c}\text { Fraksi } \\
\text { n-heksana }\end{array}$ \\
\hline Saponin & + & + \\
\hline Triterpenoid & - & - \\
\hline Steroid & - & - \\
\hline Alkaloid : & - & - \\
- R. Mayer & - & - \\
- R. Dragendroff & + & - \\
\hline Flavonoid & - & - \\
\hline
\end{tabular}

\section{KESIMPULAN}

Hasil penelitian yang telah dilakukan dapat disimpulkan bahwa sebagai berikut :

1. Ekstrak $n$-heksana berpengaruh sebagai antibakteri terhadap pertumbuhan bakteri Escherichia coli pada konsentrasi 2000 ppm dengan zona bening rata-rata 1,75 $\mathrm{mm}$ dan tidak berpengaruh terhadap bakteri Staphylococcus aureus dan Salmonella typhi. Ekstrak metanol tidak berpengaruh sebagai antibakteri terhadap pertumbuhan bakteri Escherichia coli, Staphylococcus aureus dan Salmonella typhi.

2. Dugaan golongan senyawa aktif ekstrak $n$-heksana adalah saponin sedangkan ekstrak metanol adalah saponin dan alkaloid. 


\section{SARAN}

Penelitian ini agar mendekati sempurna saran yang perlu diperbaiki dari penelitian ini, diantaranya yaitu:

1. Perlu dilakukan penambahan variasi pelarut yang lebih banyak mencakupi senyawa polar, semi polar, dan polar.

2. Perlu dilakuakan metode pemisahan yang lain seperti menggunakan metode fraksinasi untuk memperoleh rendemen yang lebih banyak.

3. Perlu dilakukan pengujian lebih lanjut dengan KLTA yang dilanjutkan dengan KLTP, identifikasi senyawa dengan instrumen FTIR, dan H-NMR.

\section{DAFTAR PUSTAKA}

Bordbar, S., Anwar, F., dan Saari, N. 2011. High-Value Components and Bioactives from Sea Cucumbers for Functional Foods-A Review. Journal Marine Drugs: 1660-3397.

Dewi, H., Silsia, D., dan Susanti, L. 2010. Ekstraksi Teripang Pasir (Holothuria Scabra) Sebagai Sumber Testosteron Pada Berbagai Kecepatan dan Lama
Pengadukan. Jurnal Pengembangan Teknologi Kimia Untuk Pengolahan Sumber Daya Alam Indonesia: 16934393.

Farouk, Ghouse dan Ridzwan. 2007. New Bacterial Species Isolated from Malaysian Sea Cucumbers with Optimized Secreted Antibacterial Activity. American Journal of Biochemistry and Biotechnology: 1553-3468.

Hudaya, S. dan Daradjat, S. 1981. DasarDasar Pengawetan I. Departemen Pendidikan dan Kebudayaan, Jakarta.

Martoyo J., Aji N. dan Winanto T. 2000. Budidaya Teripang. Jakarta: Penebar Swadaya.

Volk, W.A., dan Wheeler, M.F., 1993, Mikrobiologi Dasar, Jilid I, Alih Bahasa: Markam, Erlangga, Jakarta.

Wawolumaya, 2012. Potensi Antibakteri Pada Beberapa Jenis Teripang (Stichopus spp.) Yang Berasal Dari Perairan Lampung Selatan. Jurnal Skripsi Fakultas Perikanan dan Ilmu Kelautan Universitas Padjajaran. 